\title{
イチゴ実生の組織培養苗を用いた効率的な炭疽病抵抗性評価法
}

\author{
平島敬太 $*$ ・片山貴雄 ${ }^{\mathrm{a}}$ ・石井貴明・柴戸靖志 ${ }^{\mathrm{b}}$ ・三井寿一 \\ 福岡県農林業総合試験場８18-8549 福岡県筑紫野市
}

\section{An Efficient Method to Evaluate Disease Resistance to Anthracnose by Tissue Culture of Strawberry Seedlings}

\author{
Keita Hirashima*, Takao Katayama ${ }^{\mathrm{a}}$, Takaaki Ishii, Yasushi Shibato ${ }^{\mathrm{b}}$ and Hisakazu Mitsui \\ Fukuoka Agriculture and Forestry Research Center, Chikushino, Fukuoka 818-8549
}

\begin{abstract}
We devised a method to evaluate anthracnose disease resistance that can generate highly accurate results on a small-scale basis in a relatively short period of time. Aseptically-sown strawberry seedlings were clonally multiplied on medium containing a cytokinin. After acclimation, resistance to anthracnose disease was evaluated by spray inoculation with Colletotrichum gloeosporioides (Glomerella cingulata) at a concentration of $1 \times 10^{4}$ spores $\cdot \mathrm{mL}^{-1}$. This approach allows the evaluation of resistance within approximately 120 days after seeding, with accuracy equivalent to that of the existing method using runner plants. The new method requires no field for inoculation, and so assessment can be completed within a small-scale, closed space such as an acclimation case. Furthermore, susceptible individual seedlings may subsequently be used as materials for genetic analysis, as these plants can be preserved as uninfected clonal seedlings.
\end{abstract}

Key Words : aseptic seeding, clonal propagation, closed space, inoculation test

キーワード : 閉鎖空間，クローン増殖，無菌播種，接種検定

\section{緒言}

Colletotrichum gloeosporioides（完全世代 Glomerella cingulata）の感染で発生するイチゴ炭疽病は, 西南暖地の イチゴ栽培に拈いて最重要病害の一つである。近年の夏季 の高温傾向に伴い，育苗ほ場では萎调や枯死による多量の 苗不足が発生し, 定植後の汪場では欠株被害が増加傾向に ある。炭疽病の防除は, 雨よけ育苗や薬剂防除によって効 果を上げている（石川，2005）ものの, 食品に対する消費 者の安全志向の高まりとともに, 農薬依存度の少ない抵抗 性品種への期待が大きくなっている。これまでに，森ら （2002）扣よび森・北村（2008）による ‘サンチーゴ’，“か 打り野”, 野口ら（2006）による ‘いちご中間母本農 2 号”, 沖村ら（2008）による ‘カレンベリー’が炭疽病抵抗性品 種として登録されているが, 依然その他多くの主要品種は, 抵抗性を保有していない.

2013 年 11 月 30 日 受付. 2014 年 8 月 26 日 受理. 本研究の一部は, 園芸学会平成 20 年度春季大会で発表した.

* Corresponding author. E-mail: k-hira@farc.pref.fukuoka.jp

a 現在 : 福岡県朝倉農林事務所

b 現在 : 福岡県農林業総合試験場豊前分場
炭疽病抵抗性品種の評価・選抜法として，株から切り離 した葉柄の一端を胞子懸濁液に浸漬し, 病斑長の差により 判定する方法（野口ら，1994），栄養繁殖株に胞子懸濁液 を噴霧接種して発病程度から判定する方法（片山ら，2008）, 自殖実生群への胞子懸濁液噴霧接種により親個体の抵抗性 を評価する方法（森・北村，2010）などがある.これらの 方法は，実生個体を評価する際にはランナ一苗を増殖して 供試する，または自殖実生を再度養成する必要があるため, 養成に 1 年以上の期間が必要となることや栽培中の微生物 感染による拮抗作用の影響などが危惧される，また，播種 $40 \sim 60$ 日後の実生に胞子懸濁液を噴霧接種し, 生き残っ た株を選抜する実生幼苗スクリーニング法（森, 2003）は, 短期に小規模で選抜できる利点を持つものの，その後の栽 培には隔離湆を必要とすることや罹病性個体が枯死する ため遺伝解析を目的とする際は使用できない.

イチゴの栽培種 Fragaria $\times$ ananassa はへテロ性八倍体 であり，ゲノム解析やマーカー開発が比較的困難な種と考 えられていた. しかし，二倍体野生種 Fragaria vesca に続 きFragaria $\times$ ananassa でもゲノム情報が解読されたこと (Hirakawa 5，2014），重要な表現形質に連鎖する高密度 な DNA マーカーが開発されたこと（Isobe ら，2013），炭 疽病抵抗性に関しても QTL 解析と異質倍数性を示唆する 
報告（飯村ら，2012）など, 栽培種イチゴのゲノムやDNA マーカー情報を利用した遺伝解析を進める環境が整いつつ ある.

そこで, 炭疽病抵抗性の評価法について, 罹病性個体を 含むすべての評価個体を損ならことなく遺伝解析に利用で き, 隔離湟を必要とせず, 比較的短い所要時間で, 精度 の高い評価が得られる方法の実現を目指した. そのために, 実生クローンを組織培養で育成したのち, その順化苗に対 して順化に利用した容器内で引き続き病原菌接種を行らこ とによる, 小規模で効率的な抵抗性評価法を考案したので 報告する。

\section{材料および方法}

\section{1. 分生胞子接種濃度の検討}

炭疽病抵抗性指標品種として ‘ちご中間母本農 2 号” (以下， “農 2 号”という), 罹病性指標品種として ‘さちの か’, ‘とよのか’，“福岡 S6 号” (商標名 “あま打う’ 以下, “あま物ら”という）を用いた。指標品種は，ランナー先 端を表面殺菌して成長点近傍組織を切り出し， $\alpha$-ナフタ レン酶酸（以下，NAA） $0.01 \mathrm{mg} ・ \mathrm{~L}^{-1}$ を含む無機塩類を $1 / 2$ に減じた Murashige \& Skoog の培地（以下，1/2 MS 培地と いら）に置床育成した。 その後，30～50日抢きに新培地 へ培養容器当たり 5 本植えで継代して維持した。培養環境 は気温 $25^{\circ} \mathrm{C}$, 照度 $5 \mathrm{klx}$ の 16 時間照明とし, 培養容器は プラントボックス（外寸 $75 \times 75 \times 100 \mathrm{~mm}$ ）を用いた. 順化予定日の $30 \sim 50$ 日前に根を切除した草丈約 $2 \mathrm{~cm} の$ 株を NAA $0.01 \mathrm{mg} \cdot \mathrm{L}^{-1}$ を含を $1 / 2 \mathrm{MS}$ 培地飞置床し, 発根 した草丈約 $3 \mathrm{~cm}$, 葉数 4 枚に成長した段階で順化した. すなわち，ポリプロピレン製順化ケース（外寸 $74 \times$ $40 \times 38 \mathrm{~cm})$ 内のバーミキュライトを詰めた 72 穴セルト レーに発根した培養苗を植光付けて, 底面から給水した。 その後, $25^{\circ} \mathrm{C}$ に設定した自然光型人工気象器に移し, 遮 光率 $51 \%$ の寒冷紗下で管理した. 3 日後からケース上部の 蓋を徐々にずらして内部の湿度を落とし，7 日後にセルト レーに植え付けた状態のままで, 生育のそろった 3 株を 4 反復で接種試験に供試した. 培養苗の植え付け拈よび順化 から接種後評価までの間, 肥培管理は無肥料とした。

C. gloeosporioides の分生胞子懸濁液は, PDA（Potato Dextrose Agar）培地上の菌叢周辺部からコルクボーラーで 切り拔いた菌系を液体 PD (Potato Dextrose) 培地に植菌し, 7 日間振とう培養した懸濁液をろ過して調整した. 分生胞 子懸濁液は, $1 \times 10^{2}, 1 \times 10^{3}, 1 \times 10^{4}, 1 \times 10^{5}$ 打よび $1 \times 10^{6}$ 個・ $\mathrm{mL}^{-1}$ 亿調整し, 株当たり $2 \mathrm{~mL}$ を噴霧接種した. その後, 24 時間は順化ケースを密閉保湿して $28^{\circ} \mathrm{C}$ 恒温の 暗黒条件下で感染を促した. 続いて, 遮光率 $51 \%$ の寒冷 紗で遮光した自然光条件下 $25^{\circ} \mathrm{C} て ゙$ 管理した. 発病調查は, 接種 $3 ， 6 ， 9 ， 13$ 日後に展開した上位 4 葉について発病指 数を 5 段階区分 $(0:$ 無病徵, $1: 5 \mathrm{~mm}$ 以下の病斑, 2 : $5 \mathrm{~mm}$ 以上の病斑, 3 : 葉柄折損, 4 : 葉柄枯死）として調査
し, 株単位での平均值を求めた。

\section{2. ランナー苗と培養苗の発病様相 \\ 1) 指標品種}

炭疽病抵抗性の品種として, “農 2 号”, “サンチーゴ’, “宝 交早生”を, 罹病性品種として, ‘さちのか’, ‘とょのか’, “あま打ら”を用いた。

ランナー苗は, ビニルハウスに抒いて 2006 年 6 月 12 日 に $9 \mathrm{~cm}$ ポリポットに採苗し, 活着後に切り離して用いた. 培養土は市販品（苺ポット培土，（株）トーホー）に苦土 石灰を $2 \mathrm{~g} ・ \mathrm{~L}^{-1}$ 混合して使用した。追肥は袋入り緩効性 肥料（オクダーケ 40 , チッソ旭肥料（株）， 1 袋当たり $\mathrm{N}$ : $\left.\mathrm{P}_{2} \mathrm{O}_{5}: \mathrm{K}_{2} \mathrm{O}=280: 240: 280 \mathrm{mg}\right)$ を 1 ポットに 1 袋ずつ施 用した。接種試験は， 1 区 10 株の 3 反復で実施した. 2006 年 9 月 12 日に $1 \times 10^{5}$ 個・ $\mathrm{mL}^{-1}$ に調整した $C$. gloeosporioides の胞子懸濁液を株当たり $10 \mathrm{~mL}$ 噴霧接種し た，その後，15 時間は八ウスを密閉して湿度を保ち，感 染を促した。接種 $3 ， 8 ， 12 ， 23 ， 33 ， 43$ 日後に葉柄の発 病指数を片山ら（2008）に準じて, 0～5の6段階区分 $(0$ : 無病徵, $1: 1 \mathrm{~mm}$ 以下の病斑, $2: 1 \sim 3 \mathrm{~mm}$ の病斑, 3 : $3 \mathrm{~mm}$ 以上の病斑, 4 : 葉柄折損, 5 :株の枯死）で調査した.

培養苗は, 指標品種のランナー先端より, 「分生胞子接 種濃度の検討」と同様の方法で育成して， 1 区 4 株を 3 反 復で配置した。 2007 年 9 月 12 日に $1 \times 10^{4}$ 個・ $\mathrm{mL}^{-1}$ に調整 したC. gloeosporioides の分生胞子懸濁液を株当たり $2 \mathrm{~mL}$ 噴霧接種し, 上記の「分生胞子接種濃度の検討」と同様に 接種 $2 ， 5 ， 7 ， 9 ， 12 ， 14$ 日後に発病指数を調査した.

ランナー苗と培養苗の指標品種間の発病指数の有意差 検定には Tukeyの多重比較検定（Statistix 7, Analytical Software）を適用した.

\section{2）抵抗性品種自殖実生}

炭疽病抵抗性品種の“農 2 号” の自殖種子を2 006 年 5 月に濃硫酸を用いたプライミング処理を行い, $1 / 2 \mathrm{MS}$ 培 地を充填したプラントボックス 15 個に約 $1 \mathrm{~cm}$ 間隔で無菌 播種した。本葉 4 枚の展葉を認めた実生 200 個体を播種 25 日後から 40 日後に順次 6-ベンジルアミノプリン $0.5 \mathrm{mg}$ ・ $\mathrm{L}^{-1}$, カイネチン $1 \mathrm{mg} ・ \mathrm{~L}^{-1}$ を含む $1 / 2 \mathrm{MS}$ 培地飞葉柄基部 が培地に没するように深く移植した，先の 40 日後に，多 芽体様の状態に達した実生 180 個体の腋芽を各 5 個に分割 し, $0.01 \mathrm{mg} \cdot \mathrm{L}^{-1}$ の $\mathrm{NAA}$ を含む $1 / 2 \mathrm{MS}$ 培地のプラントボッ クスに移植して発根を促した。播種から通算で約 100 日経 過後に, 発根して生育がそろった実生の培養苗 5 株のらち 4 株を「分生胞子接種濃度の検討」と同様に順化育苗した.

このように育苗した実生の培養苗各 4 株に対し, 同年 9 月にC. gloeosporioides の分生胞子を $1 \times 10^{4}$ 個・ $\mathrm{mL}^{-1}$ の 濃度で接種し, 接種 $7,9,12$ 日後に発病指数調查を「分 生胞子接種濃度の検討」と同様の区分で行った.

ランナー苗は, 上記の実生苗 180 個体のらち, 無作為に 選んだ 20 個体の養成を試み，生育不良の 2 個体を除く 18 個体から各 12 株を得た。すなわち, 実生の培養苗 5 株の 
らち，順化せずプラントボックスに残した各 1 株から, 再 び同様の手法で夜芽増殖し，2007 年 2 月に順化した各 4 株 を親株としてランナーを発生させた。 その後, 指標品種同 様に同年 6 月に採苗養成し，18 個体から各 12 株を得た.

C. gloeosporioides の分生胞子接種は, 同年 9 月に $1 \times$ $10^{5}$ 個・ $\mathrm{mL}^{-1}$ の濃度で実施し, 接種 $21 ， 28 ， 35$ 日後に発 病指数調査を「ランナー苗と培養苗の発病様相」と同様の 区分で行った.

ランナー苗と培養苗両方の発病指数を調查した実生 18 個体で，スピアマン順位相関係数検定（4 steps エクセル統 計,（有）オーエムエス出版）を用い，調查日ごとに両発 病指数の間の相関を評価した.

\section{結果}

\section{1. 分生胞子接種濃度の検討}

分生胞子接種濃度を $1 \times 10^{2} \sim 1 \times 10^{6}$ 個・ $\mathrm{mL}^{-1}$ とし, 接 種 3，6，9，13 日後の発病指数を品種間で比較した結果を 第 1 図に, 発病状況を第 2 図に示した.

接種濃度 $1 \times 10^{2}$ 個・ $\mathrm{mL}^{-1}$ では, 全品種ともに病徵の進 行が緩やかで, 13 日後の発病指数は $0.3 \sim 1$ の範囲にとど まり, 品種間に明膫な差が認められなかった。接種濃度 $1 \times 10^{5}$ 扤よび $1 \times 10^{6}$ 個・ $\mathrm{mL}^{-1}$ では, すべての指標品種 で 3 日後から発病指数 2 の明膫な病斑が観察され，13 日後 には発病指数 4 に達した. 品種間差は, 調査期間を通じて 認められなかった。接種濃度 $1 \times 10^{4}$ 個・ $\mathrm{mL}^{-1}$ においては, 接種 3 日後にすべての指標品種で病斑が確認されたが, 発 病指数に明確な差がなかった. しかし，6日後以降は，抵 抗性品種 “農 2 号” の病徵の進行が停滞し, 罹病性 3 品種 との差が日を追うごとに明瞭となった。従って, 接種濃度 $1 \times 10^{4}$ 個・ $\mathrm{mL}^{-1}$ に抢いて, 接種 6 日後以降に発病指数を 調査することが, 抵抗性の識別に適していると考兄られた.

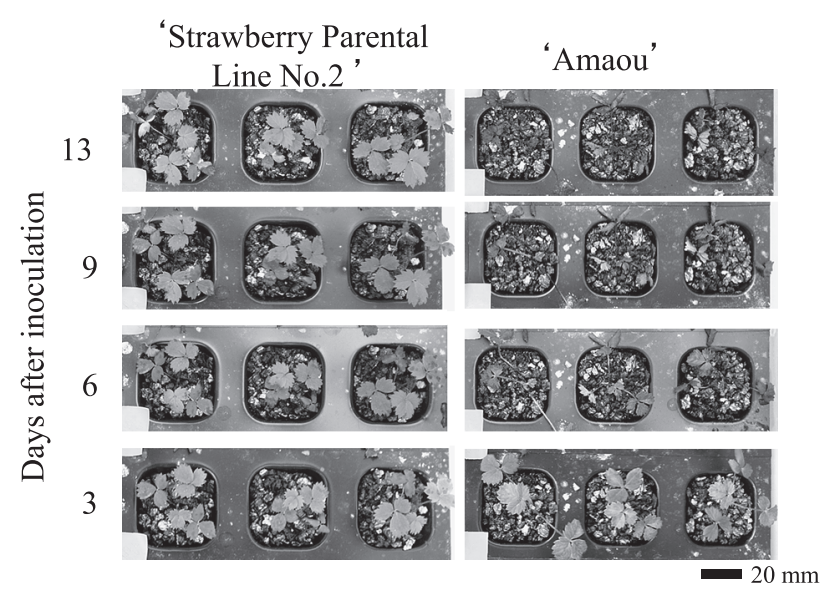

Fig. 2. The difference in progression of anthracnose symptoms on tissue culture of plants between 'Strawberry Parental Line No.2' and 'Amaou'.

Inoculum concentration of conidiospores was $1 \times 10^{4}$ spores $\mathrm{mL}^{-1}$.

\section{2.ランナー苗と培養苗の発病様相}

\section{1）指標品種}

指標 6 品種のランナー苗に抢ける炭疽病接種後の発病推 移を第 3 図左に示した

ランナー苗の指標品種に执いて最も病徵の進行が早かっ たのは，“さちのか’であり，接種 43 日後に枯死した。最 も低い発病指数で推移したのは，“農 2 号’で，接種 33 打 よび 43 日後の発病指数は，2 程度と低かった。罹病性 3 品種と抵抗性 3 品種は，前者に含まれる とよのか’ と後 者の ‘サンチーゴ”間を除き，接種 33 日後以降に 2 群に 分離した。

同様に 6 品種の培養苗に打ける炭疽病接種後の推移を第 3 図右に示した.

罹病性 3 品種は, そろって病徵の進行が早く, 接種 12 日後に枯死した．発病指数が最も低いのは，ランナー苗と
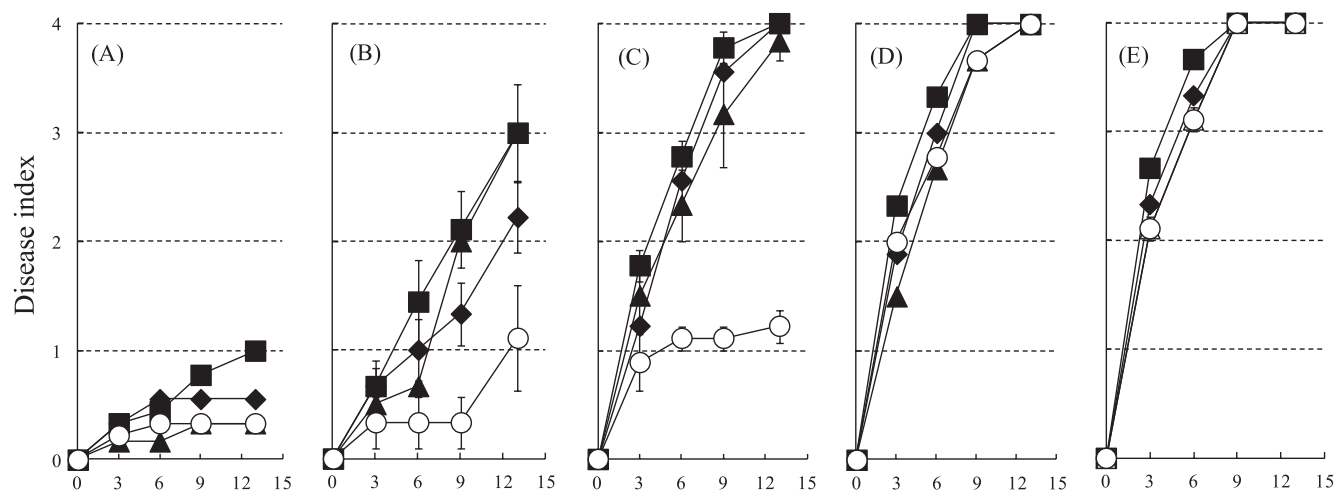

Days after inoculation

Susceptible cultivars : 'Amaou', - 'Sachinoka', $\mathbf{\Delta}$ 'Toyonoka', Resistant cultivar : O 'Strawberry Parental Line No.2 '

Fig. 1. Effect of conidiospore inoculum concentrations on the anthracnose disease index in tissue culture plants of four cultivars. Inoculum concentrations of conidiospores were (A) $1 \times 10^{2}$, (B) $1 \times 10^{3}$, (C) $1 \times 10^{4}$, (D) $1 \times 10^{5}$, and (E) $1 \times 10^{6} \mathrm{spores}^{-} \mathrm{mL}^{-1}$. Data are means \pm SE $(n=4)$. 

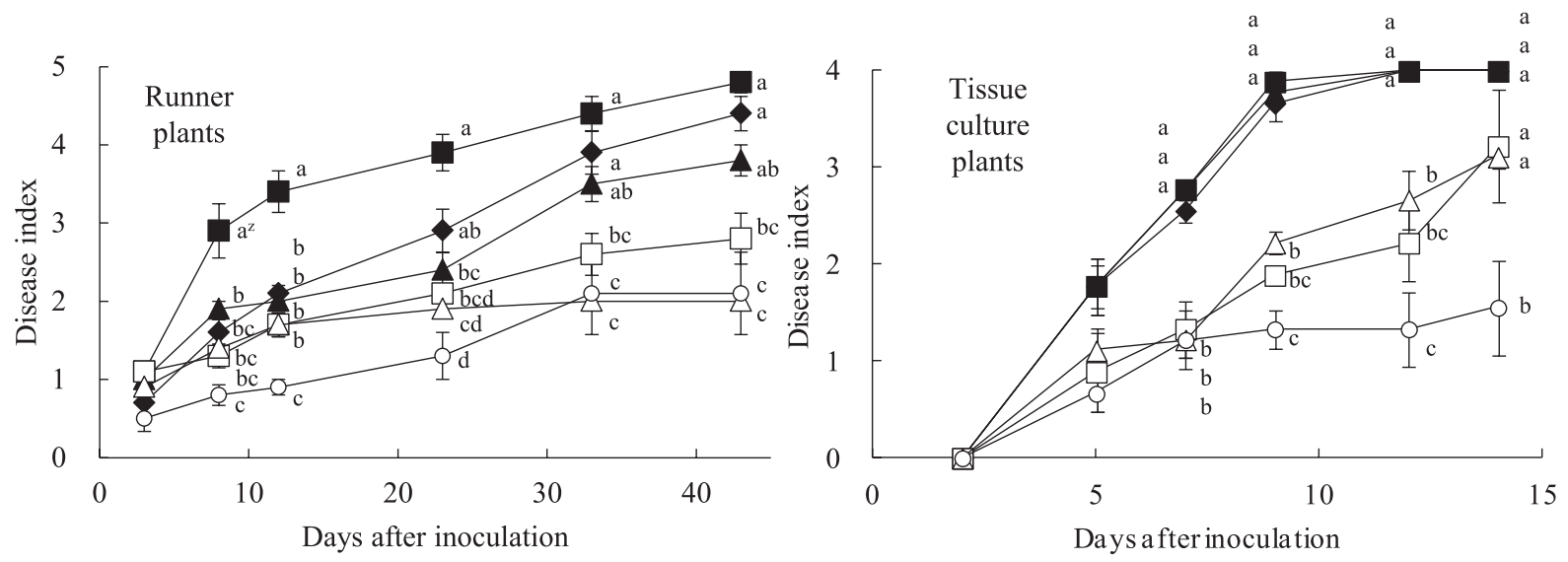

Susceptible cultivars : - 'Sachinoka', ‘Amaou', $\boldsymbol{\Delta}$ 'Toyonoka',

Resistant cultivars : $\square$ 'Sanchigo’, $\triangle$ 'Hokowase’, $\bigcirc$ ‘Strawberry Parental Line No.2’

Fig. 3. Changes in disease index after anthracnose inoculation of runner and tissue culture plants.

Data are means $\pm \mathrm{SE}(\mathrm{n}=3)$. Disease index in runner plants was graded as follows: 0: Symptomless, 1: Lesions less than $1 \mathrm{~mm}, 2$ : Lesions of 1-3 mm, 3: Lesions more than $3 \mathrm{~mm}, 4$ : Petiole fracture, and 5: Plant death.

Disease index in tissue culture plants was graded as follows: 0: Symptomless, 1: Lesions less than $5 \mathrm{~mm}$, 2: Lesions more than $5 \mathrm{~mm}$, 3: Petiole fracture, and 4: Petiole death.

${ }^{z}$ Different letters on the same day indicate significant differences among means according to Tukey's multiple range test $(P<0.05)$.

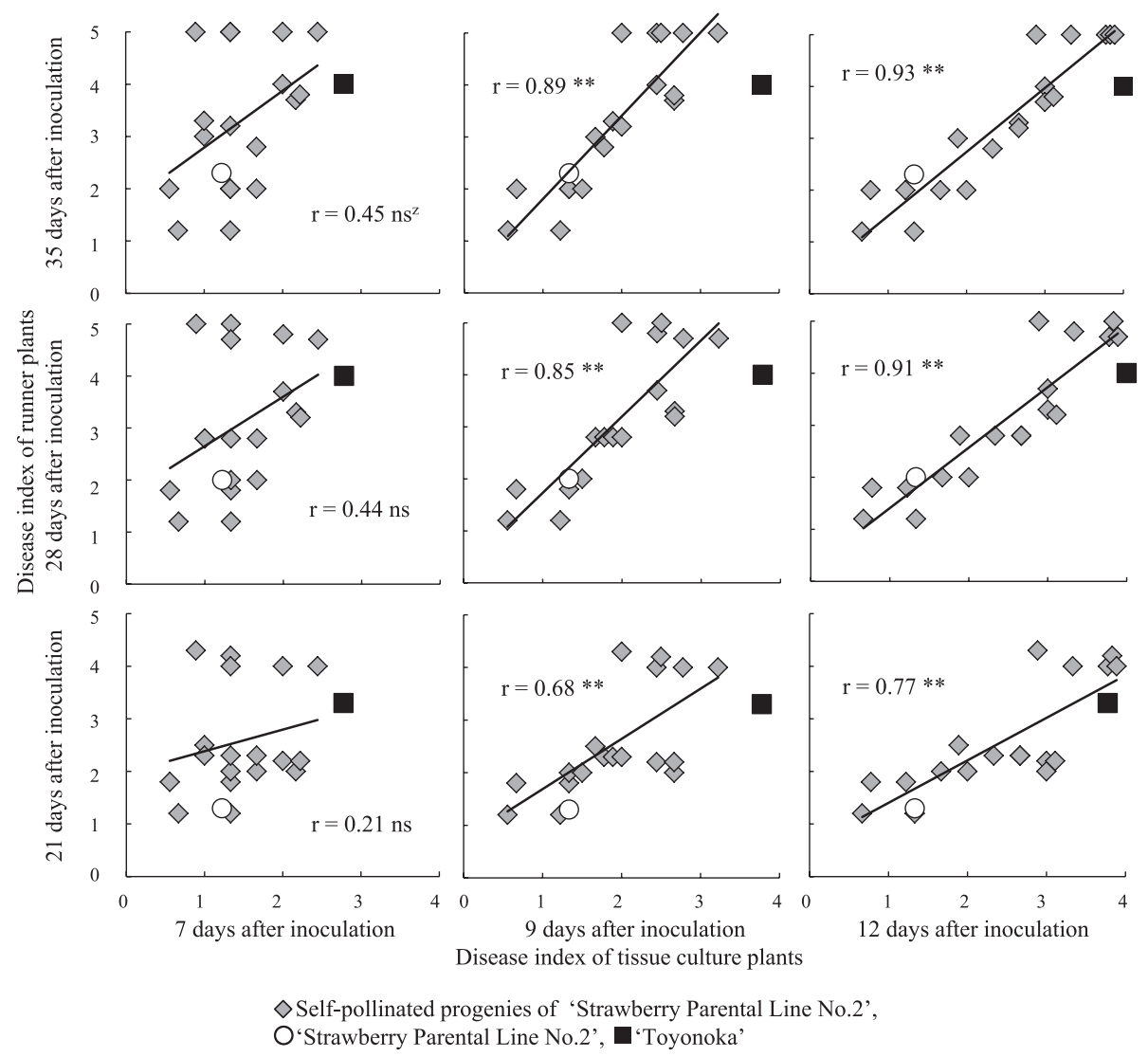

Fig. 4. Correlations of anthracnose disease index between runner and tissue culture plants in self-pollinated progenies of 'Strawberry Parental Line No.2'.

Data are means of $\mathrm{n}=12$ runner plants and $\mathrm{n}=4$ tissue culture plants.

${ }^{\mathrm{z}} \mathrm{ns}$ and $* *$ indicate non-significant and significant levels with $P<0.01$, respectively. 
同様の “農 2 号”であり, 接種 14 日後の発病指数は, 1.6 程度であった。罹病性 3 品種と抵抗性 3 品種は, 接種 7, 9, 12 日後に $2 つ$ 群に分離した. しかし, 接種 14 日後には“農 2 号をを除き，差がなくなった.

従って, 両増殖法における罹病性品種と抵抗性品種の判 別は，概ねランナ一苗では接種 33 日後以降に，培養苗で は接種 7 日後以降に可能となり, 培養苗はランナ一苗に比 べて判別に要する日数が短く, さらに罹病性品種と抵抗性 品種の差が明瞭であった。

\section{2）抵抗性品種自殖実生}

“農 2 号” の自殖実生のランナ一苗と培養苗に打ける炭 疽病接種 7,9, 12 日後の発病指数の相関を第 4 図に示した.

接種後日数に関わらず, ランナ一苗の発病指数と培養苗 の接種 9 日後抏よび 12 日後の発病指数との間に相関が認 められた. ランナ一苗と培養苗の発病指数の相関は, とも に接種後の日数が経過するほど高くなり，ランナ一苗の 35 日後と培養苗の 12 日後の相関が最も高くなった.

従って，培養苗を利用した炭疽病接種による抵抗性評価 では，ランナー苗に対する接種評価と同様の発病様相をよ り短期間に得られ，判定に適する接種後経過日数は 9 12 日と考兄られた。

\section{考察}

イチゴ炭疽病の発生規模と被害の程度は, $C$. gloeosporioides の感染圧と病原性の強弱（岡山, 1994）, 温湿度と拮抗微生物などの環境要因（石川，2005; 森, 1998），植物が本来持つ抵抗性の差異（石川ら，1989; 沖村 ら，2004），苗齢（森，2001; Smith ら，1990）に影響を受 汀る. 本試験では, 罹病性個体であっても未感染のin vitro のクローンを維持できることを前提とした。 そして， 順化後間もない培養苗に拈けるイチゴ炭疽病の抵抗性評価 について最適条件を明らかにするとともに, 閉鎖容器内で の接種試験により環境要因を安定させ，苗の個体間䛊差を 減らすために生育のそろったクローン個体を組織培養によ り確保することで, 植物が本来持つ炭疽病抵抗性の差異を 明確にしょらとした. 加えて，小規模の閉鎖空間に抌いて 短期間での評価を目指した。

本試験の分生胞子接種濃度は, $1 \times 10^{2} \sim 1 \times 10^{6}$ 個・ $\mathrm{mL}^{-1}$ として，接種 $3 \sim 13$ 日後の発病指数を抵抗性品種と 罹病性品種間で比較した。 その結果, 接種濃度 $1 \times 10^{4}$ 個・ $\mathrm{mL}^{-1}$ に扔いて，6日後以降に抵抗性品種と罹病性品種との 差が明瞭となった。実生幼苗やランナ一苗を用いた既報 (Smith ら, 1990; 森，1998，2001，2003; 森ら，2002; 野口ら, 2006; 片山ら，2008; 森・北村，2008，2010）では，1 $5 \times 10^{5}$ 個・ $\mathrm{mL}^{-1}$ の濃度範囲が利用されている. 一方で, 今回の培養苗に対する接種では, それよりも濃度の低い $1 \times 10^{4}$ 個・ $\mathrm{mL}^{-1}$ の接種に拈いて品種間差が明確に示され た. Smith ら（1990）や森（1998，2001）は，植物体の苗齢 や生育差の違いが発病度やその進行に影響すると報告して
いることから，これらの結果は，通常のランナ一苗に比べ てょり未熟な培養苗を接種に用いたことが，接種濃度が低 い条件であっても，その後の発病度の進行を促進した要因 と考学られる. 従って, 順化直後の培養苗はランナ一苗や 鉢上げ直後の実生に比べて，C. gloeosporioides に対する 抵抗性が相対的に低い（感受性が高い）状態にあると推察 された。

指標 6 品種のランナ一苗と培養苗の発病様相を比較した 結果では，培養苗はランナ一苗に比べて判定までの所要 日数が短く，さらに罹病性品種と抵抗性品種の差が明瞭 であった。これらの結果は，抵抗性のレベルが低い（感受 性が高い）状態の培養苗に沶いても，品種固有の罹病性と 抵抗性の相対的関係が維持されていることを示している. 従って，本実験で用いた培養苗の評価系は従来のランナー 苗に比較して同様の抵抗性反応をより短期間により明瞭に 把握できると考えられる.

現実の育種場面で供試される交雑後代を想定して，“農 2 号’の自殖実生個体をランナ一苗と培養苗で比較した結果 に扣いて，両者の発病指数には接種後日数が進むほど高い 相関が認められた。最も両者の相関が高かったのは，ラン ナ一苗 35 日に対する培養苗 12 日であり, 約 $1 / 3$ の接種後日 数で同様の抵抗性評価を得ることが可能であった。 これら の結果は，実生の幼苗の発病が成苗に比較して早く，両者 には高い相関があるとした森の報告（1998）に対し，本試 験は同一クローンに拈ける培養苗とランナ一苗の比較と育 苗法の違いはあるものの, 同様に幼弱な苗を接種評価に用 いることの有用性を示す点で一致するものと考えられる.

これらのことを総合すると，所要期間は短く，小規模で の評価選抜が可能な利点を持つものの罹病性株が枯死して 失われる森（1998，2003）の方法に対して，本法は，罹病 性個体であっても未感染の in vitro のクローンを接種個体 とは別途に維持でき, 遺伝解析の材料として引き続き利用 可能な点が特に有用である。

抵抗性評価の面では，無菌播種約 30 日後の実生を腋芽 増殖してクローンを養成し，順化 7 日後に分生胞子を接種 することにより，12 日後には片山ら（2008）の方法と同 様の精度で抵抗性評価が可能となる。播種から抵抗性判定 までの合計した所要期間は 120 日程度であるため，実生個 体の栄養繁殖を必要とする片山ら（2008），野口ら（1994） の方法, ならびに自殖後さらに次世代の育成を必要とする 森・北村（2010）の方法に比べて短期間に結果が得られる.

また，接種評価に拈ける誤差の一つである環境要因につ いて，無菌環境下からの順化間もない個体を利用すること で，接種病原菌以外の拮抗性作用を示すような微生物感染 の影響を最小限にとどめることが可能である。ささら，育 苗規模についても本葉 4 枚程度の小さな株を用いるため小 面積で高密度（72穴セルトレー利用時には約 243 株・ $\mathrm{m}^{-2}$, また 128 穴セルトレーを利用できることも確認しており， その場合には約 432 株・ $\mathrm{m}^{-2}$ ) に管理できる利点を持つ. 
加えて, 閉鎖空間としての順化ケースを利用して分生胞子 の接種評価を完了できることから, 外部への病原菌の拡散 を防ぐことができる、そして，これまでの接種評価法は， 発病適温の夏季に限定して実施されていたが, 本法は, 組 織培養と小規模評価を特徵とするため, 環境制御装置利用 が容易で, 周年評価への応用が可能である.

以上のことから，イチゴ実生の組織培養苗を順化して接 種試験に用いる炭疽病抵抗性評価手法は, 若齢実生株を用 いた接種試験と同等以上の小規模短期評価を可能にし，栄 養繁殖株を用いた接種試験と同等の精度で抵抗性を評価で きると考えられる。

しかしながら, 以上の様な利点を持つ反面, 一般的な実 生の育成管理に比べて, 無菌操作や順化作業, 恒温室など が別途必要となる点は改善の余地が大きく, 今後の課題で ある.

\section{摘 要}

イチゴの炭疽病抵抗性評価において, 小規模に比較的短 い所要日数で, 高い精度の評価結果が得られる抵抗性評価 法を考案した。無菌播種した実生をサイトカイニンを含む 培地でクローン増殖し, 順化後の個体に $1 \times 10^{4}$ 個・ $\mathrm{mL}^{-1}$ 濃度のC. gloeosporioides 分生胞子を接種することにより, 播種後約 120 日の所要期間で, 従来のランナー苗接種評価 と同程度の高い精度の抵抗性評価が可能である。本法は, 幼弱な培養苗を用いて順化ケースなどの小規模な閉鎖空間 で評価を完遂できるため，接種用の浪場を必要としない. さらに，罹病性個体を損ならことなく未感染のクローン苗 として維持できるため, 引き続き遺伝解析の材料として利 用可能である.

\section{引用文献}

Hirakawa, H., K. Shirasawa, S. Kosugi, K. Tashiro, S. Nakayama, M. Yamada, M. Kohara, A. Watanabe, Y. Kishida, T. Fujishiro, H. Tsuruoka, C. Minami, S. Sasamoto, M. Kato, K. Nanri, A. Komaki, T. Yanagi, Q. Guoxin, F. Maeda, M. Ishikawa, S. Kuhara, S. Sato, S. Tabata and S. N. Isobe. 2014. Dissection of the octoploid strawberry genome by deep sequencing of the genomes of Fragaria species. DNA Res. 21: 169-181.

飯村一成・田崎公久 - 中澤佳子・天谷正行. 2012. QTL 解析によるイチゴ炭疽病耐性遺伝子領域の検索. 育学 研. 15: 90-97.

石川成寿. 2005. イチゴ炭疽病の病原菌, 生態ならびに環 境に配慮した防除技術開発. 栃木農試研報. 54: 1-187.
石川成寿・中山喜一・大兼善三郎. 1989. イチゴ炭そ病に 対する品種間差異. 関東東山病虫研報. 36: 85-86.

Isobe, S., H. Hirakawa, S. Sato, F. Maeda, M. Ishikawa, T. Mori, Y. Yamamoto, K. Shirasawa, M. Kimura, M. Fukami, F. Hashizume, T. Tsuji, S. Sasamoto, M. Kato, K. Nanri, H. Tsuruoka, C. Minami, C. Takahashi, T. Wada, A. Ono, K. Kawashima, N. Nakazaki, Y. Kishida, M. Kohara, S. Nakayama, M. Yamada, T. Fujishiro, A. Watanabe and S. Tabata. 2013. Construction of an integrated high density simple sequence repeat linkage map in cultivated strawberry $($ Fragaria $\times$ ananassa) and its applicability. DNA Res. 20: 79-92.

片山貴雄・末信真二・三井寿一・浜地勇次. 2008. 噴霧接 種法を用いたイチゴ炭疽病抵抗性の評価方法. 福岡農 総試研報. 27: 39-43.

森 利樹. 1998. 実生幼苗を利用したイチゴ炭そ病抵抗性 の選抜に及ぼす管理温度の影響. 園学雑. 67: 934-938.

森 利樹. 2001. イチゴに扣汀炭そ病抵抗性の遺伝と選 抜反応. 三重農技七研報. 28: 15-21.

森 利樹. 2003. イチゴ炭疽病抵抗性の遺伝的特性と育種. 植物防疫. $57: 271-275$.

森 利樹・北村八祥. 2008. か扣り野. 品種登録 22218 .

森 利樹・北村八祥. 2010. イチゴ自殖実生を用いた後代 検定による炭疽病抵抗性評価法の開発. 園学研. 9: 137-141.

森 利樹・戸谷 孝・藤原孝之. 2002. サンチーゴ. 品種 登録 10373.

野口裕司・望月龍也・沖村 誠・曽根一純. 2006. いちご 中間母本農 2 号. 品種登録 13757.

野口裕司・望月龍也・山川 理. 1994. 葉柄接種によるイ チゴ炭そ病抵抗性簡易選抜法の開発. 野菜茶試研報 A. 9: $13-26$.

岡山健夫. 1994. イチゴ炭々病菌 Glomerella cingulata（= Colletotrichum gloeosporioides) 分生子の飛散および障 壁による防除効果. 日植病報. 60: 113-118.

沖村 誠・野口裕司・望月龍也 - 兽根一純・北谷恵美. 2004. 炭そ病抵抗性の「いちご中間母本農 2 号」の育 成とその特性. 園学研. 3:257-260.

沖村 誠 - 曾根一純 - 野口裕司 - 望月龍也 - 北谷恵美. 2008. カレンベリ一。品種登録 22564.

Smith, B. J., L. L. Black and G. J. Galletta. 1990. Resistance to Colletotrichum fragariae in strawberry affected by seedling age and inoculation method. Plant Dis. 74: 1016-1021. 